\title{
On the Qing Tributary System from the Perspective of Transaction Cost
}

\author{
Huanhuan Yu \\ Jinan University, Guangzhou, China \\ Email: 494880509@qq.com
}

Received 16 March 2016; accepted 19 April 2016; published 22 April 2016

Copyright (C) 2016 by author and Scientific Research Publishing Inc.

This work is licensed under the Creative Commons Attribution International License (CC BY). http://creativecommons.org/licenses/by/4.0/

(c) () Open Access

\begin{abstract}
The Qing tributary system, which is centered on China, has been regarded as a universally acknowledged and distinguished regional order in pre-modern East Asian. This system is made up of a series of informal, formal institutions and the system of governance. Such system can get a good explanation by using the transaction cost theory of new institutional economics. It is obvious that the available literature about the tributary system rarely involves transaction cost theory; so this paper tries to analyze the Qing tributary system from this perspective and break the traditional analytical paradigm of international relations scholars, and then tries to build and sum up the two explainable models about the system of rising and recession.
\end{abstract}

\section{Keywords}

Transaction Cost, Tributary System, Institutional Cost, Path Dependence, Path Lock

\section{Introduction}

The term of the tributary system describes the regional order in pre-modern East Asia. It is centered on the Qing dynasty and surrounding states (such as North Korea, Viet Nam, Okinawa) tribute to China. In this system, tribute and trade are often closely interwoven; the Qing puts a high value on the symbolic meaning of tribute, while the neighboring states pay more attention to the benefits of trade. But in exchange, they recognize the Qing as the center of the world, and the Qing grants these tributary states the convenience of economic and trade. Centering on tributary activities forms a series of institutional arrangements.

\section{Transaction Cost Theory and Its Application on Politics}

The term "transaction cost" is frequently thought to have been coined by Ronald Coase, who used it to develop a theoretical framework for predicting when certain economic tasks would be performed by firms, and when they 
would be performed on the market [1]. In his paper The Nature of the Firm [2], he firstly discusses the concept of transaction cost. And then his student Williamson developed his ideas and enlarged the transaction cost theory, his ideas focus on these works: Markets and Hierarchies: Analysis and Antitrust Application [3], The Economic Institutions of Capitalism [4] and The Mechanisms of Governance [5]. They lay the foundation on transaction cost economics.

Influenced by Econimics, there are some papers that apply transaction cost into politics to analyze institution, political organization and so no. Moe [6] delivered the paper, The New Economics of Organization, applying organization theory of new institutional economics to study public bureaucracy. In the paper-The Industrial Organization of Congress; or, why Legislatures, Like Firms, Are not Organized as Markets-Weingast and Marshall [7] used the transaction cost theory to explain the legislative system. North [8] formally introduces the concept of transaction costs into political science in his paper, A Transaction Cost Theory of Politics, and he comes to the conclusions that the political market tend to be more inefficient. Dixit [9] formally proposed the concept of transaction cost politics in his works, The Making of Economic Policy: A Transaction-cost Politics Perspective. Vira [10] went even further, he established the Political Coase Theorem. Sandler and Cauley [11] adopted the concept of transaction cost to explain how supranational structure design.

In this paper, we agree to the definition of Cheung [12], he think that transaction cost is not conceivable in a "Robinson Crusoe economy", in other words, transaction cost is institution cost, any costs that arise from the existence of institutions. Why is it possible to analyze international relations from the perspective of transaction cost? My answers base on the following factors:

Firstly, they share the similar assumptions between the state actors among political activities and the individual among economic activities. They are supposed to rational actors and only have limited rationality, they have a strong of opportunism, and they follow the principle of utility maximization to act.

Secondly, in order to reduce transaction cost, there appear institutions. The tributary system could be regard as the assembly of institutions, which is made up of a series of informal and formal institutions and the system of governance.

Thirdly, the rise and fall of the tributary system relates to transaction cost. When the external transaction cost could be successfully converted to institutional cost, the tributary system can normally operating, once it couldn't, the expensive institutional cost couldn't sustain the tributary system.

On the basis of the above reflect, my following analysis are like this: In paragraph 2, I discuss the rise of the tributary system, to reduce transaction cost between states, the tributary system is made. Paragraph 3 talks about the institution in tributary system, and Paragraph 4 discuss the fall of the tributary system, I point out that the Qing cannot assimilate external transaction cost into tributary system as well as ever-increasing internal cost account for the fall of the tributary system.

\section{Transaction Cost Analysis on the Rise of the Tributary System}

The tributary systems in East Asia are constituted by the Qing and the surrounding small countries. Relaxing this strictly meaning of the term of the "States", we can regard these political actors as the "State" in the modern sense. From the perspective of transaction cost, first of all, we need to put the following basic assumptions about the country:

Firstly, the states are rational actors. The states have the ability to conduct any sensible analysis of the costs and benefits, and they know how to take actions to make their national utility maximization. These utility of national interests includes not only material wealth but also seeking the prestige, status and honor and other intangible factors.

Secondly, the states have only limited rationality. The states have limited information, coupled with the complexity of the state environment, different national preferences and cognition, each state's rationality is limited. It is impossible to know all of the information in the system and make the right response.

Thirdly, the states have a strong sense of opportunism. The identity of the state constructs their national interests, and their national interests construct acts. In pursuit of its own national interests, there are strong incentives encouraging them take actions in the way of opportunism, which means that the states could be opportunistic, deliberately hide information to their detriment, fraud, bad faith, contrary to the rules of the system for personal gains.

Fourth, the states follow the principle of utility maximization. The states always can maximize the utility 
within the constraints of the system. Its utility includes not only material benefits but also the optimal combination of power, prestige and status.

International relations scholars, usually think tributary system is often seen as the hegemonic order, which is based on the China' power and its cultural advantage, so it is an unequal distribution of power. Put aside the power, the strength and such as these typical terms in international relations, we try to explain the origin of this system from the perspective of transaction cost.

The primary premise of the formation of an international system is that the states must have a certain degree of self-awareness to distinguish between themselves and other, this is the prerequisite and basis for international interaction. Only when the states are aware of another country it dealing with rather than belong to part of itself, the states can be regarded as the independent actors. The self-awareness of the state make itself having a clear understanding of their situation, and also has a certain degree of understanding and awareness about another state, although these may not be appropriate. Constant interaction between the two countries makes the formation of a loose international system. We call it the "thin" international system and the original form of system, which does not mean that there are some links between different states on the culture, rules or institutions.

During the process of interaction, the states will adjust their knowledge in different context and form the different cognitive schema. The schema involves formation and distribution of shared ideas between states. In the process of interaction between the Qing and the surrounding states, they gradually come to the consensus on the following matter: the Qing is the largest country in the region, its power and culture are superior. So it's natural, also is beneficial, to pay tributary to it. Such knowledge becomes the inter-subjectivity and forms an idea, it can be referred to as ideology or belief system in the broad meaning.

These belief system or ideologies shaping some rules of conduct such as a conscious tributary acts, etiquette and behavior patterns of interaction. And these practice lead to the emergence of the informal institutions of practice. Informal interaction every time can be regarded as a transaction, in this exchange, the core status of the Qing has been universally-acknowledged. The Qing fully shows its soft power and national prestige and satisfaction. At the same time, the surrounding states get the real material interests and trade privilege, they announced their regime's legitimacy and the protection of national security under the behavior of tribute. Under the exchange activities of the tributary system, national utility function gets the maximum protection. This series of transactions include the complex multilateral trade on each state, like the political prestige of the Qing exchange the political legitimacy of the neighboring states, border security of the Qing exchange the guarantee of independence of the neighboring states and the political prestige of the Qing exchange the economic and trade interests of the neighboring states. This multilayered trade is profitable for each state. During the continuing deal, sometimes even developing the frequent speculative trading, the Qing spends a large number of money to receive and reward the neighboring states. At last, the Qing is aware of that it must establish more specific institutions and standardize tributary activities so as to save transaction costs. The Qing establishes the specific tributary institutions among time, place and gifts, so it is tribute etiquette. More details of tributary trade rules established, which is clearly identified with a specific tributary legislation. Most of the informal institutions have been absorbed and evolved into the formal system.

Tributary trade activities carry out under the cover of these recognized ideologies, informal and formal institutions. Transaction costs is mostly absorbed by the institutions and become the institutions cost. These costs include the negotiated cost for the establishment of the institutions, extra costs by unforeseen events lead to and the operating and maintaining cost of the institutions. Only when these institutions cost far less than the tributary benefiting of utility functions, it is smart to set up this institution, Tribute is a profitable deal.

In the early Qing dynasty, this system does take effect. The existence of the tributary institutions greatly reduce risk and uncertainty, much less the negative externalities of the tributary system by internalize external costs of this system. Thus, the system in which we can see an interactive model:

National self-awareness-sustained interaction led to the thin international system-form and distribute the shared ideas-informal institutions appear-partly evolves formal institutions-form the thick international system. During the process of evolution of the tributary system from thin to thick, a dark thread associate with this process: the external transaction costs convert into institutional cost and the benefits of tributary trading activity far more than institutional cost, tributary transactions maximize both utility functions, makes the deal having continued momentum going under the constraints of the institutions. Now we turn to discuss different institutions in the Qing tributary system. 


\section{Transaction Cost Analysis on the Institutions of the Tributary System}

Tributary system can be seen as the process when external transaction costs realize internalization depending on the institutions. The existence of transaction costs contribute to the tributary system changing from thin to thick. Williamson [13] divided the institution into four levels: embedded, institutional environment, system of governance and allocation of resource and employment. Learned from Williamson's research, we found that, in addition to the micro-level resource allocation and employment only can be restored to states actors, three additional levels exist at the system level.

First of all, we can find the informal institutions in the tributary system. These rules include general tributary specification, custom and values, whose core part is the shared ideology, including on the universe of views, the concept hierarchic, Confucian thought and diplomatic principles between states. These concepts became intersubjectivity between the States, qualified the contextual meaning of tributary, give birth to official trading institutions and interactive mode, along with these official institutions reduced the risk-run of the system and the uncertainty of the state contacts, last reduced transaction cost.

The states usually been seen as the selfish rational actors, but we do find a lot of ethical behavior of altruism in the tributary system. Most of the time in the face of border and territorial disputes, the Qing does not rely on its own strength or threat, but ceded territory to neighboring countries. Such ethnical behavior, in my opinion, should return the world concept of the Qing to look for, that is the ancient Chinese view of "under heaven", which is distinct from the modern territorial concept in the West. The Qing regards all neighboring states as a member of family, and all of states have no clear of territory concept, as long as they recognized the Qing' highest status in the name. In the light of the comity principles between states, land of transferring can be regarded as the gift and non-humiliation. It is beneficial for both to exchange politics with land.

What's more, there exist the formal institutions in tributary system. These specific institutions include the arrangement on the time, place, gift to tribute as well as the institutions on trade and etiquette. They are formal, should be strictly adhered to, and they rule the neighboring states with clear legal provisions. Under the normal circumstances, informal institutions often allow flexible, formal institutions do not allow the discount. The neighboring states have no right to change the regular way to tribute, or go beyond ritual to meet their requirements. If tribute is not the subject of their own native products, the states will also be determined. The delicate and complicate tributary rituals can be used on formal occasions before following the walkthrough.

Finally, the system of governance plays the important role. In the tributary system, there are four different governance structures: bilateral governance, autonomous governance, third-party governance and unified governance. From the Qing' point of view, the interactions between it and each tributary States form bilateral governance and neighboring states each other form autonomous governance. When the Qing mediates around the conflicts and disputes among the tributary States as the Supreme authority, there comes out the third-party governance. At last, the Qing is seen as the supply and coordinator of the tributary system, which lead the system and grasp the whole system, this can be called the unified governance. These four patterns interweave and form a complex governance network. Among these governance structures, the Supreme authority of the Qing and the independence of the neighboring states have been guaranteed. Due to the system has a lot of resilience and flexibility, the Qing less spends on administration fee and reduces transaction cost. Once the external and internal transaction cost soar, the Qing's governance has to face the crisis.

\section{Transaction Cost Analysis on the Fall of the Tributary System}

Explaining the fall of the tributary system is a major challenge because new institutional economics tends to uphold the progressive view of institutional change. In their views, institutional change is endogenous and usually suggests the new institution seems better. This paper does not deny this, but how to explain the system function effectively in the early, while the latter inevitably recess and is replaced by the new system. North studied the path dependence, he points out that the locked path leads to the inefficiency of the institutions. Such interpretation is useful, but not enough to explain the system. Even North [14] also sad to admit that the scholars couldn't find a reasonable interpretation to explain the recession of institutions. But this does not mean that the transaction cost theory is useless.

This paper argues that the ultimate demise of the tributary system is due to the collapse of the tributary institutions. At the late of the tributary system, institutional costs is too high to burden on the continue existing of the system. The states cannot be able to make a profit later. The cause of the high cost is as follows: 
1) External cost substantially increases at the late of the tributary system. The cause of the increases can be find both on internal and outside the system. The most important is the impact of the West. Under the strong impact of the West, The Qing cannot not only squeeze the western powers out of the East Asia but also intake these states into the tributary system. Lord Macartney visiting China marks the failure of the Qing trying to huairou (the Chinese word, means conciliate) the West into the tributary system as well as internalizing external cost. In order to maintain tributary system, The Qing has to devote more resources and energy. For example, the Qing was forced to at war with Japan just to maintain tributary relationship between Qing and Korea, eventually it was defeated and paid a huge sum of compensation to Japan. The high external cost of the tributary system far more than institutional cost, which reduced to the Qing have to reluctantly abandon the tributary system.

2) Path dependent leads to locked. Due to the irreversibility of time, in the tributary system, the rules and institutions formed a fixed mode and is repeatedly reinforced by practice. At the late of the tributary system, the system lost its energy and innovation and then the fixed tribute model make the path locked. In this case, partly due to lack of vitality and adaptability, the Qing cannot take effective measures to response to internal and external shocks. If it want to break the path lock, the system often requires a strong external shock, for example, war or major incident, known as the "Olsen shocks”.

3) Ideological rigidity. Once ideologies formed, it would become a powerful tool of social reality. It is prone to be conservative, lagged and inalienable, as a result, become negative factors in the development of the system. The impact of the West was not one-time shock leading to the decline of the tributary system. Because of ideological rigidity, the old tributary system also stubbornly resisted the impact of the West. It is too high to strip the old ideology to accept the new ideology for the States within the tributary system, which account for ideological change lagging behind the changes of the system. At last, ideological rigidity become the obstacle of changing the tributary system.

So, we summary the decline model of the tributary system. Path dependent leads to locked, along with ideological rigidity hold back changing the tributary system, along with the extrusion of the external force makes system cannot internalize the external cost. All of these factors account for the high cost of the institutions. When it breaks down, the tributary also cannot sustain.

\section{Conclusions}

From the perspective of transaction cost, this paper analyzes the Qing tributary system. According to whether the tributary system successfully transforms external system cost into the institutional cost and profit from the system, the tributary system has experienced two distinct periods. At the early age, the Qing successfully transforms external system cost into the institutional cost, and depends on the system to maximize the state' utility. At the late of the tribute system, because the Qing could not effectively internalize the external costs arising from the impact of the West, in addition to path locked due to path dependence and ideological rigidity, the operating cost of the tributary system is extremely high and its revenue has plummeted, which declare the death of the tributary system. Although the Qing tried to save and adapt the system, its efforts did not help and the tribute system eventually quit the stage of history.

Studying the historical heritage of the tributary system, useful lessons can be drawn as follows:

Firstly, the existence of the successful system needs to have good institution support. The normal operation of the institutions needs to make institutional gains greater than the institutional cost. In that case, the sensible national actors are willing to maintain and sustain the institution and accept the institutional arrangements.

Secondly, the institution itself is not static. In specific contexts, the institution should have some of flexibility. The states should encourage innovation and incremental changes in the system and adapt flexible institutions according to the specific situation in order to reduce the cost and risk of accidents. In addition to, the locked path should be on the alert, once the locked path appears, more efficient measures should be taken to break the routine.

Last but not the least, it should be noted the complex effect of ideology. Positive ideology greatly reduces transaction costs and maintains the operation of the system. But when the ideology becomes behind social reality, ideology will be converted to conservative. Rigid ideology stubbornly hampered the institutional changes. Successful system should pay attention to the role of ideology and attach the important to these factors who lead to change. 


\section{References}

[1] Wikipedia Contributor. Transact Cost (2016) From Wikipedia, the Free Wikipedia. https://en.wikipedia.org/wiki/Transaction cost

[2] Coase, R. (1937) The Nature of the Firm. Economica, 16, 386-405. http://dx.doi.org/10.1111/j.1468-0335.1937.tb00002.x

[3] Williamson, O. (1975) Markets and Hierarchies: Analysis and Antitrust Application. Free Press, New York.

[4] Williamson, O. (1985) The Economic Institutions of Capitalism. Free Press, New York.

[5] Williamson, O. (1996) The Mechanisms of Governance. Oxford University Press, New York.

[6] More, T.M. (1984) The New Economics of Organization. American Journal of Political Science, 4, 739-777.

[7] Weingast, B.R. and Marshall, W.J. (1988) The Industrial Organization of Congress; or, Why Legislature, Like Firms, Are Not Organized as Market. Journal of Political Economy, 1, 132-163. http://dx.doi.org/10.1086/261528

[8] North, D.C. (1990) A Transaction Cost Theory of Politics. Journal of Theoretical Politics, 4, 355-367. http://dx.doi.org/10.1177/0951692890002004001

[9] Dixit, A. (1996) The Making of Economic Policy: A Transaction-Cost Politics Perspective. MIT Press, Cambridge.

[10] Vira, B. (1997) The Political Coase Theorem: Identifying Differences between Neoclassical and Critical Institutionalism. Journal of Economic Issues, 3, 761-779. http://dx.doi.org/10.1080/00213624.1997.11505964

[11] Sandler, T. and Cauley, J. (1977) The Design of Supranational Structures. International Studies Quarterly, 2, $251-276$. http://dx.doi.org/10.2307/2600296

[12] Cheung, S.N.S. (1999) The Paradigm of Transaction Cost. Social Science Front, 1, 1-9.

[13] Williamson, O.E. (2002) The Theory of the Firm as Governance Structure: From Choice to Contract. Journal of Economic Perspectives, 3, 171-195. http://dx.doi.org/10.1257/089533002760278776

[14] North, D.C. (1993) The New Institutional Economics and Development. General Information, 9, 1389-1395. 